\title{
Library Anxiety: A Grounded Theory and Its Development
}

Constance A. Mellon

This qualitative study explored the feelings of students about using the library for research. Personal writing, collected in beginning composition courses over a two-year period, was analyzed for recurrent themes. It was found that 75 to 85 percent of the students in these courses described their initial response to library research in terms of fear. Three concepts emerged from these descriptions: (1) students generally feel that their own library-use skills are inadequate while the skills of other students are adequate, (2) the inadequacy is shameful and should be hidden, and (3) the inadequacy would be revealed by asking questions. A grounded theory of library anxiety was constructed from these data.

study conducted at a southern university with six thousand students explored the feelings of students as they did research in an academic library for the first time. This study is unique for two reasons. First, it applied rarely used methods of qualitative research to a library problem. Second, to collect data for the study it used classroom techniques that were taken from the "Writing across the Curriculum" movement. The following essay presents both the study and the theory behind the study. The intent is not only to share research findings with colleagues but to stimulate interest in an alternate research methodology that seems useful in a profession whose major aim is service to people.

\section{THE THEORETICAL PERSPECTIVE OF QUALITATIVE RESEARCH}

To understand how the theory outlined in this paper was developed, it is important to understand the method by which it was derived and how that method differs from the quantitative techniques traditionally used in the field of library science. Drawing upon large samples to represent the populations to be studied, quantitative techniques use statistics to predict how and why people behave as they do under certain conditions. These techniques are useful in studying the causes and consequences of things people experience in library settings.

On the other hand, qualitative studies focus on viewing experiences from the perspective of those involved: users, librarians, and administrators. There is an attempt to understand why participants in a library setting react as they do. This may be accomplished by applying research methodologies from areas where the traditional focus has been the in-depth study of people, i.e., the ethnographic techniques of anthropology and the qualitative methods of sociology. ${ }^{1}$ They involve the gathering and analyzing of descriptive data in an attempt to see a setting or an experience from the participants' point of view. This holistic approach tries to describe all the bits and pieces, the variables, that compose an individual's world rather than trying to control for them as in quantitative approaches.

To view the world through the eyes of their subjects, qualitative researchers

Constance A. Mellon is assistant professor in the department of Library and Information Studies, East Carolina University, Greenville, North Carolina 27834. 
have used a variety of techniques that are limited only by the imagination of the researcher. Although the techniques are rigorous and empirical, aimed at as full a description of the situation under study as possible, researchers have successfully combined existing techniques and created new ones in an attempt to study and define events as they are experienced by real people in their everyday lives. A number of these techniques aim toward collecting data that Robert Bogdan and Steven Taylor call "personal documents. ${ }^{\text {"2 }}$ Many of these personal documents yield data that are strikingly similar to the "personal writing" that composition theorists encourage as a general learning activity.

\section{PERSONAL DOCUMENTS AND PERSONAL WRITING}

Bogdan and Taylor define personal documents as "an individual's descriptive, first-person account of the whole or part of his or her life or an individual's reflection on a specific topic or event.",3 One category of personal documents included transcripts of unstructured interviews. These are frequently long, open-ended conversations that capture an individual's perspective of a situation, event, or activity. Personal documents can also include autobiographies, diaries, and letters written either for the self or at the request of a researcher.

Bogdan and Taylor's description of personal documents bears a marked resemblance to the initial stage of the writing process described by composition theorists. ${ }^{4}$ During the first stage of the writing process, sometimes called " personal writing," the writer is talking on paper with no concern for audience, style, or the rules of grammar and spelling. This technique allows the writer to tap into a stream of consciousness, thus uncovering personal knowledge, interests, and conclusions about a topic. ${ }^{5}$ Since personal writing can help one to clarify and organize thoughts and to produce better papers, activities such as free writing (writing steadily for short periods, putting down thoughts as they occur) and journal writing (diarylike entries on specific aspects of a subject) should be used in teaching writing. ${ }^{6}$ Free writing or journal writing can also provide a rich source of qualitative data on students' perceptions of any activity or idea that the instructor may wish to explore.

\section{ANALYZING QUALITATIVE DATA}

The type of data gathered for qualitative analysis is very different from the type of data quantitative researchers collect. It generally consists of several hundred written pages that reflect the perspectives of many individuals. Before discussing how such data are analyzed, the goal of this type of analysis needs to be understood. Unlike quantitative research where the goal is to produce a replicable study, one in which two researchers working with the same methodology would arrive at the same conclusions, qualitative analysis is intended to produce a unique theory grounded in the situation or event under study. The theory is written in narrative form, incorporating descriptions and quotations taken from the data to "describe the social world studied so vividly that the reader, like the researcher, can literally see and hear its people."

The analysis of qualitative data using the constant comparative method is an ongoing process that is closely integrated with the data collection process. ${ }^{8}$ The primary purpose of this analysis is to discover themes, topics, or situations that occur in the conversations or writings of respondents. These themes are used to construct hypotheses or to develop ideas about how individuals define themselves, their activities, or the events or organizations in which they participate.

\section{DEVELOPING GROUNDED THEORY FROM PERSONAL WRITING: AN EXAMPLE}

As part of an ongoing effort to understand students' perceptions of the library research process, a component of a funded project to integrate library instruction into beginning composition courses at a southern university, twenty English instructors assigned and collected personal writing from students in their composition classes over a two-year period. 
Instructors required students to keep search journals. These were diarylike entries that described the search process and the students' feelings about it. In addition, toward the end of the semester, students were required to do an in-class essay that addressed variations of four basic questions:

- What were your experiences using the library to find information for your research paper?

- How did you feel about the library and your ability to use it?

- Did these feelings change over the course of the semester?

- How do you feel about using the library now?

Data were collected each semester from participating instructors and were analyzed for recurrent "themes" using the constant comparative method. It was found that 75 to 85 percent of students in each class described their initial response to the library in terms of fear or anxiety. Terms like scary, overpowering, lost, helpless, confused, and fear of the unknown appeared over and over again. A description from the journal of a freshman is typical of the feelings expressed by these students:

Using the library is a scary prospect, especially when I think about in-depth research. I know that research cannot be done without frequent visits to the library and I know that nothing in here will hurt me but it all seems so vast and overpowering.

Some students described their fear as a "phobia." As one student explained, 'I'll admit I'm one of those people who has a library phobia." This phobia caused students to describe library use as a "nightmare," something they "dreaded all semester." A student described her thoughts about beginning research for her paper in this way,

Oh! Now I have to begin my research paper and what am I to do? Although I have been using the University's library for a little more than one semester, I'm still frightened each time I push those wide glass doors apart!

Most of the students who discussed their fear of the library talked about the feeling of being "lost." One student claimed she felt like "a lost child," another that she was "lost in there and actually scared to death," while a third declared,

I, as many freshmen, was lost in the library for a very long time. It was like a big maze to me and was easy to get lost in.

Feelings of being lost stemmed from four causes: (1) the size of the library; (2) a lack of knowledge about where things were located; (3) how to begin, and (4) what to do. Again and again, students mentioned the "large size" of the library. (Actually, the study was conducted in a relatively small academic library of only three floors.) A student explained, "I relate my fear of the library .... to its large size," and another declared that "the largest library I'd ever been in seemed like a small room compared to this." Instead of a paragraph, one student produced a list of words that included "big, expansive, vast, majestic, awesome." Another declared, "The library seems like a huge monster that gulps you up after you enter it."

Confusion about where things were located was a second theme that appeared frequently in students' writing. "This library stuff is confusing,," one student printed in big capital letters. "Where are the reference books? Which card catalog do I use? There are so many drawers!" Another student declared, "I have no idea where the encyclopedias are. I don't even know where to go to find out where those type of books are." Later she added, "Oh, well. I guess I'll make it-somehow!"

In flowing handwriting, a student summed up the feelings expressed by many of her peers,

When I first entered the library, I was terrified. I didn't know where anything was located or even who to ask to get some help. It was like being in a foreign country and unable to speak the language.

Two related themes, how to begin and what to do, also appeared with great frequency as students wrote about their library experience. "I've always been lost when I do research at the library," wrote one student. "I never know where to begin looking for information." Another de- 
clared, "I am always puzzled as to what step to take first." And a third explained, "I knew where the card catalogs were, but there were so many little drawers, I wouldn't even know where to start."

While some students worried where to begin, others expressed their concern about what they were supposed to do in the library. "I don't understand this library system at all!"' a student printed angrily across his paper. "I spend an hour or two in the library every day," wrote another, " but I still don't know what's going on." A third explained rationally, "The library can be an overwhelming place to someone who doesn't understand how to use it."

Descriptions such as these led to the formulation of a grounded theory that when confronted with the need to gather information in the library for their first research paper many students become so anxious that they are unable to approach the problem logically or effectively. The question arises, Why didn't students explain their lack of library skills to their professors? Further examination of the data indicated that students' fears were due to a feeling that other students were competent at library use while they alone were incompetent, that this lack of competence was somehow shameful and must be kept hidden, and that asking questions would lead to a revelation of their incompetence.

"I can't believe I don't know anything about this!" wrote one student who signed "Knucklehead." Another declared, "They never taught me how to use the library. I guess they thought I would already know." A third student added, "As soon as you enter the university, you are expected to know how to use the library."

The feeling that students should already know how to use the library for research led to the concern one student explained this way: "I tend to feel like I'm the only one in the university that doesn't know where to look for things in the library."

A feeling of inadequacy in comparison to others can cause a continuing incompetence when students do not ask questions because they fear revealing their ignorance. "I'm shy and afraid to ask ques- tions," wrote a student, while another explained, "I was scared to ask questions. I didn't want to bother anyone. I also didn't want them to think I was stupid."

\section{THEORY INTO PRACTICE}

The final stage of qualitative research involves examining the grounded theory developed for a specific situation or event in terms of existing research. In this study, the original purpose of collecting data was to help find better ways to teach search strategy and tool use within the fiftyminute session allotted by the composition faculty. The intent was to use the findings to shed light on the increasing literature about how library instruction should be accomplished. It was discovered, however, that when asked about using the library for research, students did not discuss the problems they encountered with search. Instead, they discussed feelings of fear that kept them from beginning to search or that got in the way of their staying in the library long enough to master search processes. The library phobia that they described seemed to tie in closely with the work being done on math and test anxiety. ${ }^{9}$ It thus seemed logical to describe students' fear of the library as $l i$ brary anxiety and to consider treating it within the anxiety framework.

The literature indicates that acknowledging the anxiety and its legitimacy, and then providing successful experiences to counteract the anxiety, is the most effective method for treatment. While we considered it unlikely that composition faculty would radically revise their courses to incorporate more sessions on library use, we began sharing our findings with supportive colleagues in the English department to determine where changes could be made to acknowledge and deal with library anxiety.

A cooperative relationship had existed between the instruction librarians and the composition faculty prior to the study; however, this cooperation was mainly in the form of a fifty-minute "orientation seminar" conducted by librarians early in the semester. Due to insufficient library staffing for instruction, it was planned to design a library instructional session to be 
given by composition faculty as part of their course work. However, the data indicated that library anxiety was considerably reduced by interaction with a librarian in the fifty-minute orientation session. While the librarians were aware that fifty minutes did not provide sufficient time to develop a real working grasp of search strategy, or even tool use, they were unaware of the importance students placed on "getting to know the librarian" and "realizing those people really want to help me." The resulting redesign continued to include a fifty-minute library instruction session that we called our "warmth seminar." Although search strategy and tool use were still emphasized, the redesign provided maximum interaction between student and librarian. In addition, instruction librarians incorporated information about library anxiety into their presentations. They assured students that this anxiety was both common and reasonable.

Composition faculty began to devote classroom sessions to library instruction, and accompanied their students to the library. Faculty positioned themselves at a table near the reference desk and acted as a liaison between their students and the reference librarians. As they worked more closely with the librarians serving their students, the faculty became more knowledgeable about library search strategies. This resulted in a better professional relationship between librarians and faculty and in more realistic library research assignments from instructors who began to appreciate the intricacies of using the library. Composition faculty had formerly spent only one class session in the library. Now they conducted more than half their class sessions there.

Formulating a grounded theory of library anxiety and examining its underlying causes helped librarians and composition faculty to understand better the problems students encountered in using the library for research. From these observations, a closer cooperation between composition faculty and librarians resulted. This changed both the presentation of library research in beginning com- position classes and the design of the library-instruction program.

\section{IMPLICATIONS OF THE STUDY FOR LIBRARY INSTRUCTION}

There are a number of ways in which the findings of this study might be of value to those involved in library instruction. First, the study documents students' attitudes toward library research and presents a theory to explain these attitudes. Why is this important? librarians might ask. The lack of library skills is no surprise to reference or instruction librarians. Most of them know students are afraid of the library and know why. Our faculty colleagues, however, do not often know this. In my experience, providing people with documentation is faster and more effective than any arguments I can muster from my library expertise. After all, we have known for years that tests and mathematics make many students anxious; however, until the theories of "test anxiety" and "math anxiety" appeared in the literature, no programs existed to deal with these anxieties. Good qualitative research can provide us with the theoretical labels and documentation we need to support and legitimize our commonsense knowledge.

Second, the study can provide a new direction for research in the field of library instruction. While most of us are aware that fifty minutes allows only the rare few to master either tool use or search strategy very little has appeared in the literature about being warm, friendly, and approachable. While we may assume everyone already knows this, many instructors try to pack everything the student should know into the precious fifty-minute slot. I understand the need to share all we know with students whom we fear we may never see again. I also understand the feeling of failure when our empathy with the group tells us they haven't understood or don't care about anything we said! This is quite different from perceiving an instruction session as a "warmth seminar." In this session, our primary goal is to help students see the library as a great place with fascinating information and warm, 
friendly people available to help them. We can pass out handouts that tell students how to use the Readers' Guide and an assignment that verifies they used it, but only a good instruction librarian can convince them the library isn't scary.

Finally, there are the implications of this study. Many librarians have been confused by the literature on the evaluation of library instruction and the difficulty of documenting instructional effectiveness. But with the goal of alleviating library anxiety as an important initial emphasis in a library instruction program and with the use of classroom writing to gather data, instruction librarians are provided with a new standard and a new technique for documenting the effectiveness of their programs. It is hoped that further evaluation studies will use this technique and that the results will expand the dimensions of the theory of library anxiety.

\section{IMPLICATIONS OF QUALITATIVE DATA FOR LIBRARY STUDIES}

While this research study is important, the implications of the research technique are far greater. The major aim of librarianship is to bring people and relevant information together. While measurement has its uses, measurement alone does not provide us with an understanding of the people we serve. Techniques such as the one described above not only can provide an understanding of our users but can do so without disrupting the service upon which our field is based. It is vital to emphasize that good qualitative research carries with it a demand for rigor and excellence, a demand as strong as that of its quantitative counterpart. However, it may also provide a fresh approach toward user services and a research option for a different type of researcher.

\section{REFERENCES}

1. Robert Bogdan and Steven J. Taylor, Introduction to Qualitative Research Methods: A Phenomenological Approach to the Social Sciences (New York: Wiley, 1975); James P. Spradley and David W. McCurdy, The Cultural Experience: Ethnography in Complex Society (Chicago: Science Research Assoc., 1972).

2. Bogdan and Taylor, p.6-7.

3. Ibid., p.96.

4. James Britton, Language and Learning (Harmondsworth, England: Penguin, 1970); Janet Emig, The Composing Process of Twelfth Graders (Urbana, Ill.: CTCE, 1971); Linda Flower and John L. Hayes, "A Cognitive Process Theory of Writing, " College Composition and Communication 32:365-87 (Dec. 1979); James Moffet, Teaching the Universe of Discourse (Boston: Houghton, 1968).

5. James Moffet, "Writing, Inner Speech, and Meditation," College English 44:231-46 (Mar. 1982).

6. Denny Wolfe and Robert Reising, Writing for Learning in the Content Areas (New York: J. Weston Walch, 1983).

7. Barney G. Glaser and Anselm L. Strauss, The Discovery of Grounded Theory: Strategies For Qualitative Research (Chicago: Aldine, 1967), p. 228.

8. Ibid., p. 107-15.

9. Sheila Tobias, Overcoming Math Anxiety (Boston: Houghton, 1980). 


\section{"I used to shudder when patrons requested information on a proceedings paper."}

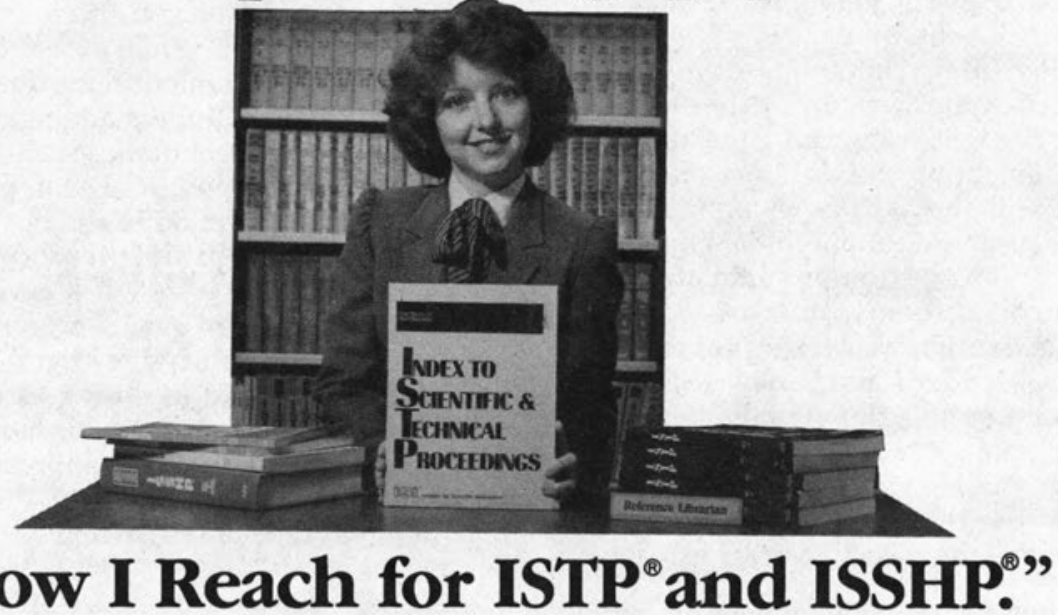

\section{"Now I Reach for ISTP ${ }^{\circledR}$ and ISSHP."}

Now you too can get easy access to individual papers published in conference proceedings ... with the Index to Scientific $\&$ Technical Proceedings ${ }^{\oplus}$ and the Index to Social Sciences \& Humanities Proceedings ${ }^{\circ}$. Each year, ISTP indexes over 123,000 individual papers, and ISSHP over 21,000. Over $70 \%$ of this material is not indexed in the Science Citation Index ${ }^{\circledR}$ or in the Social Sciences Citation Index

Since the proceedings literature is generally the first place where early research results appear, you'll find ISTP and ISSHP useful for bibliographic verification, retrospective searches - even for current awareness! Any of six access points quickly lead you to complete descriptions of proceedings and the individual papers presented in them. And the main entries display proceedings in a contents-page format-ideal for easy scanning. Each entry provides the full bibliographic information you need.

Why not make these valuable indexes part of your library's reference collection? A yearly subscription to ISTP is $\$ 775$, and to ISSHP is $\$ 575$.

For more information-and to receive your FREE sample issue of ISTP or ISSHP-just fill out and mail the coupon below. Or call us toll-free 800-523-1850, extension 1371.

Remember, no literature search is complete without checking the proceedings in ISTP or ISSHP.

\footnotetext{
Please send me a free sample issue of the index l've checked below. I understand there is no cost or obligation.

$\square$ Index to Scientific \& Technical Proceedings* monthly issue

$\square$ Index to Social Sciences \& Humanities Proceedings* quarterly issue

Name/Title

Organization/Department

Address

City

Country

- 20

$\square$ Institute for Scientific Information

State/Province

ZIP/Postal Code

Customer Services Department, 3501 Market Street, Philadelphia, PA 19104, Tel: (215) 386-0100,137 European Office: 132 High St., Uxbridge, Middlesex UB8 1DP, U.K., Tel: 44-895-70016

들
}

1 